\title{
ŻYCIE NAUKOWE INSTYTUTU HISTORII UNIWERSYTETU W BIAŁYMSTOKU W ROKU AKADEMICKIM 2000/2001
}

Życie naukowe Instytutu Historii w roku akademickim 2000/2001 zainaugurowane zostało jeszcze przed rozpoczęciem zajęć dydaktycznych, gdyż w dniach 28-29 września 2000 r. odbyła się cykliczna Międzynarodowa Konferencja Źródłoznawczo-Historyczna Ziemie Wielkiego Księstwa Litewskiego i Podlasia. Źródta, stan badań, której IH był współorganizatorem. Uczestniczyli w niej historycy i archiwiści z Białorusi, Litwy, Łotwy i Polski, którzy wygłosili 26 referatów i komunikatów. Większość z nich poświęcona była prezentacji źródeł dotyczących omawianego obszaru, rozproszonych obecnie w archiwach na terenie różnych państw ${ }^{1}$.

W dniach 19-22 marca 2001 r. na Wydziale Historyczno-Socjologicznym odbyły się obchody jubileuszu Wydawnictwa Naukowego PWN, w których uczestniczyli pracownicy IH. Zorganizowano wystawę publikacji PWN oraz serię wykładów: prof. Pawła Wieczorkiewicza Od biatego caratu do czerwonego, prof. Aliny Witkowskiej Blaski i cienie historii literatury, dr. Mikołaja Olszewskiego Wizja filozofii średniowiecznej profesora Stefana Świeżawskiego w ksiażce „Dzieje europejskiej filozofii klasycznej” oraz Andrzeja Krzysztofa Kunerta Stosunki polsko-sowieckie 1939-1945.

Miłym akademickim zwyczajem, kultywowanym także w IH, jest świętowanie jubileuszy profesorskich. W maju $2001 \mathrm{r}$. obchodzono 75-lecie urodzin prof. Mariana Leczyka. Z tej okazji przybyło do Białegostoku wielu gości

1 Obszerne sprawozdanie $\mathrm{z}$ tej konferencji opublikowane zostało w poprzednim tomie "Studiów Podlaskich": H. Majecki, Ziemie Wielkiego Księstwa Litewskiego i Podlasia. "Źródta, stan badań. Międzynarodowa Konferencja Źródtoznawczo-Historyczna. Biatystok, 28 i 29 września 2000 r., „Studia Podlaskie” 2000, t. X, s. 427-430. 
- przyjaciół, uczniów, dawnych i obecnych współpracowników. Przygotowana została księga pamiątkowa Polska w Europie i świecie w XX stuleciu. Prace ofiarowane panu Profesorowi Marianowi Leczykowi w 75-lecie urodzin, w której znalazło się 40 artykułów historyków z IH i innych ośrodków.

Ważnymi wydarzeniami w życiu naukowym IH były kolejne publiczne obrony prac doktorskich: 19 października 2000 r. mgr Edyty Bezzubik nt. Sprawy matżeńskie przed sqdami kościelnymi w Polsce XVII wieku, 23 listopada 2000 r. - mgr. Adama Miodowskiego pt. Akcja polityczna ugrupowań demokratycznych $w$ sprawie wojska polskiego $w$ Rosji w latach 1917-1918 oraz mgr. Radosława Waleszczaka pt. Przasnysz i powiat przasnyski w latach 1866-1939 i 7 czerwca 2001 r. mgr. Artura Pasko pt. Komitet Wojewódzki PZPR w Biatymstoku w latach 1948-1956 oraz mgr Małgorzaty Dajnowicz pt. Drobna szlachta Ziemi Łomżyńskiej na przetomie XIX $i X X$ wieku.

Instytut Historii UwB od dłuższego czasu prowadzi współpracę naukową z ośrodkami akademickimi z Białorusi, Litwy, Czech, Słowacji i Francji. W ramach współpracy z Uniwersytetem im. Janka Kupały w Grodnie prowadzone są badania dotyczące czterech tematów: szlachta i ziemiaństwo na terenach tzw. „guberni zachodnich" Imperium Rosyjskiego w XIX w., miasta i miasteczka na kresach północno-wschodnich Drugiej Rzeczypospolitej, kresy północno-wschodnie w latach 1939-1945 oraz Polacy na Syberii $\mathrm{w}$ XIX w. W ramach współpracy $\mathrm{z}$ tym ośrodkiem $\mathrm{w}$ minionym roku akademickim kontynuowana była wymiana studentów - IH gościł w dniach 12-25 marca 2001 r. dziesięć osób z Uniwersytetu w Grodnie. Zaproszeni studenci odbyli spotkania z pracownikami IH i studentami historii, zapoznali się z ofertą dydaktyczną IH, wydawnictwami naukowymi, uczestniczyli w obchodach jubileuszu Wydawnictwa Naukowego PWN oraz studenckiej dyskusji panelowej nt. Unia Europejska - szansa czy zagrożenie? Odwiedzili także Archiwum Państwowe w Białymstoku, Muzeum Historyczne i Książnicę Podlaską, prowadzili kwerendy biblioteczne. Natomiast od 13 do 25 maja 2001 r. dziesięcioosobowa grupa studentów historii z Białegostoku przebywała w Grodnie. Ponadto w semestrze zimowym r. akad. 2000/2001 w IH przebywał na stażu doc. Tadeusz Kruczkowski z Uniwersytetu Grodzieńskiego. W celu omówienia dalszych kontaktów naukowych w lipcu przyjechał do IH dziekan prof. Aleksander Nieczuchrin.

Wspólnym tematem badań historyków z Białegostoku i Bratysławy jest zagadnienie pogranicza małopolsko-słowackiego do końca XVIII w. - Spisza, Orawy i Podhala. W dniach 13-16 grudnia 2000 r. z inicjatywy Władz Dziekańskich Wydziału Historyczno-Socjologicznego gościli u nas trzej naukowcy 
z Uniwersytetu w Pradze. Prof. Roman Holec wygłosił wykład nt. Stowacka emigracja do USA, dr Martin Homza - Znaczenie średniowiecznych źródet polskich dla dziejów stowackich, dr Dušan Škwarny - Rewolucja 1848-1849. Stowacy a Polacy. Goście ponadto spotkali się $\mathrm{z}$ władzami Wydziału, pracownikami IH, zwiedzali Białowieżę, Drohiczyn i Supraśl.

Ponadto prowadzona jest współpraca $z$ Uniwersytetem Karola w Pradze, dotycząca głównie zagadnienia stereotypów narodowych w Europie Środkowowschodniej oraz z Centre Roland Mousnier Universite de Paris - Sorbonne Paris IV w ramach tematu Badania nad rekonstrukcja struktury rodzin i gospodarstw domowych w Polsce $i$ Europie XVI-XVIII w. za pomoca elektronicznej techniki obliczeniowej. Częste są też kontakty historyków białostockich $\mathrm{z}$ naukowcami z Litwy - w ostatnim roku gościli u nas doc. Algis Kasperavičius z Uniwersytetu w Wilnie i dr Rimantas Miknys, wicedyrektor Instytutu Historii Litwy. W maju 2001 r. zorganizowano w Uniwersytecie w Bratysławie prezentację IH UwB, w trakcie której wykłady wygłosili prof. prof. Halina Parafianowicz, Hanna Konopka i Henryk Ruciński. Podjęto też inicjatywę nawiązania współpracy z Seminarium Geografii Historycznej Uniwersytetu w Bonn, Instytutem Historii Narodowej Akademii Nauk Białorusi w Mińsku i Niepublicznym Centrum Humanistycznym w Grodnie.

Instytut Historii uczestniczył w międzynarodowym programie SOKRATES-ERASMUS. W jego ramach prof. Daniel Grinberg w grudniu $2000 \mathrm{r}$. złożył tygodniową wizytę w Evangelisch Fachhochschulle w Darmstadt.

Ważnym elementem życia naukowego uczelni jest ruch studencki. Studenckie Koło Naukowe Historyków działające pod opieką pracowników IH wykazywało dużą aktywność. W minionym roku akademickim do istniejących już sekcji Historii Wojskowości, Historii Nowożytnej i Historii Miast dołączyły dwie nowe: Dziedzictwa Kulturowego Żydów Polskich oraz Historii Kościoła. Ich działalność to przede wszystkim prace badawcze, spotkania dyskusyjne. Organizowano również badania terenowe dotyczące architektury obronnej okresu II wojny światowej, cmentarzy: żydowskiego w Białymstoku oraz muzułmańskiego w Bohonikach, który został przez studentów zinwentaryzowany. SKNH w dniach 28-30 września 2000 r. zorganizowało studencką konferencję naukową w Supraślu nt. Maty ośrodek miejski jako miejsce ksztattowania życia spotecznego, kulturalnego, religijnego i gospodarczego.

W omawianym okresie Instytut Historii wydał następujące prace naukowe swoich pracowników: prof. Michała Gnatowskiego Niepokorna Biatostocczyzna. Opór spoteczny i polskie podziemie niepodlegtościowe w regionie 
biatostockim w latach 1939-1941 w radzieckich źródtach, prof. Henryka Rucińskiego Chrześcijaństwo na Orawie do końca XVIII wieku, mgr. Wojciecha Śleszyńskiego Biatystok w sowieckiej fotografii propagandowej 1939-1941. Proces aneksji i polityczno-prawnej sowietyzacji Biatostocczyzny, dr Joanny Sadowskiej Ku szkole na miarę Drugiej Rzeczypospolitej. Geneza, zatożenia i realizacja reformy Jędrzejewiczowskiej oraz księgę pamiątkową Polska $w$ Europie $i$ świecie $w X X$ stuleciu. Prace ofiarowane panu Profesorowi Marianowi Leczykowi w 75-lecie urodzin, pod redakcją prof. Haliny Parafianowicz. Wydany został obszerny Informator o studiach w Instytucie Historii, przeznaczony przede wszystkim dla kandydatów na studia. Ukazał się także liczący 430 stron X tom „Studiów Podlaskich” i kolejny 22 numer popularnonaukowego periodyku "Gryfita. Białostocki Magazyn Historyczny”.

Nowym akcentem w życiu Instytutu była przeprowadzona po raz pierwszy wśród studentów ankieta ewaluacyjna zajęć prowadzonych przez poszczególnych pracowników. Jej wyniki, zróżnicowane, ale na ogół pozytywne, wzbudziły duże zainteresowanie. Ustalono, iż taka ocena przeprowadzana będzie corocznie.

Uczestnictwo w przedsięwzięciach podejmowanych na miejscu, to tylko część aktywności naukowej pracowników IH. Z dużym zaangażowaniem i wkładem pracy reprezentowali oni swą placówkę na zewnątrz, uczestnicząc w kilkudziesięciu konferencjach krajowych i zagranicznych, nawiązując kontakty, publikując w pismach o szerokim zasięgu. Jest to przejaw dążeń nie tylko do własnego rozwoju naukowego, ale także budowy prestiżu białostockiego środowiska historycznego i zdobycia uznania w kraju i za granicą. 